\title{
Comparative Study of Emotional Maturity and Self Concept among Doctors and Managers
}

\author{
Sharad V. Sawalkar ${ }^{1}$, Dr. A.R. Bhardwaj ${ }^{2}$
}

\section{ABSTRACT:}

The present study evaluates the emotional maturity and self concept among Doctors and managers. The sample consisted of 100 professionals (50 Doctors and 50 Managers) from Jalgaon and Nashik cities of North Maharashtra. Self-concept rating scale, developed by Dr. Muktarani Rastogiand Emotional Maturity Scale by Singh and Bhargava Scales were used to collect the data. The data were analyzed by ' $t$ ' test. The results discovered that the Doctors and Managers have no significantly difference on emotional maturity. It was also noticed that Doctors and Managers have no significantly difference on self concept.

\section{Keywords: Emotional Maturity, Doctors, Managers}

In the present circumstances, Non Professionals as well as professionals are facing complexities in their life. These complexities are generous to many emotional problems such as frustrations, tensions, anxiety, and emotional upsets in day to day life. So, the study of emotional life is now getting bigger aspect, similar with social structure. As emotional Maturity and self concept do play essential role in the life of human being, one is probable to have higher emotional maturity in order to lead an effective for increase performance. Human behavior is continuously affected by the emotional maturity and self concept level that we possess.

The results of the present study will help to recognize Self concept and emotional Maturity of among Doctors And Managers. This will further help to identify Doctors And Managers who may have potential to be of high competence. Professionally Doctors And Managers work profile are full of challenges, so Doctors and Managers in their professional life must show the required psychological attributes including self concept and emotional Maturity to gather together the challenges effectively. The variables self concept and emotional Maturity need to be studied appropriately, both from the theoretical and practical point of view. The research can help the build up their attitude towards self and maturity to improve their performance.

${ }^{1} \mathrm{Ph}$. D. Research Scholar, North Maharashtra University, Jalgoan

${ }^{2} \mathrm{Ph}$. D. Research Guide, Principal, B.R.D. Women College, Nashik 


\section{OBJECTIVES}

i. $\quad$ To study and compare the Emotional Maturity of Doctors and Mangers.

ii. To study and compare the Self Concept of Doctors and Mangers.

\section{HYPOTHESES}

i. There exists no significant difference between Doctors and Mangers on Emotional Maturity.

ii. There exists no significant difference between Doctors and Mangers on Self Concept.

\section{DELIMITATION OF THE STUDY}

- The geographical area of the study was delimited to the Private practicing Doctors and Private sector Mangers of Nashik and Jalgaon City.

- Doctors And Mangers have been selected on simple random bases.

- Sample for the study was delimited to Doctors and Managers in the age range between 30 and 45.

- The present study is delimited to Self Concept and Emotional Maturity only.

- Only male Doctors and Managers were selected for the investigation

\section{SAMPLE:}

For this study, 100 professionals (50 Doctors and 50 Managers) in the age range of 30 to 45 years were randomly selected from the Jalgaon and Nashik District of Maharashtra state.

\section{VARIABLES:}

$\begin{array}{lllll}\text { Independent variables: } & \text { Area } & : & \text { 1. Nashik } & \text { 2. Jalgaon } \\ & \text { Profession } & : & \text { 1. Doctor } & \text { 2. Manager }\end{array}$

Dependent variables: 1 . Self concept

\section{Emotional Maturity}

\section{TOOLS:}

The following tools were used for collecting data for the study:

I. Self Concept scale by Dr. Muktarani Rastogi (1974) was used to evaluate the self-concept of the participants. Two scales -one consisting of 15 adjectives to measure psychological selfconcept and the other comprising of 10 adjectives for measuring physical self-concept were used. The lists of adjectives were presented with 7-point rating scale.

II. Emotional Maturity Scale (EMS) (Singh \&Bhargava(1991)this scale has 48 questions related to the following 5 categories: Emotional Regression, Emotional Instability, Social Maladjustment, Personality Disintegration and Lack of Independence. The test-retest 


\section{Comparative Study of Emotional Maturity and Self Concept among Doctors and Managers}

reliability has been estimated at 0.75 and validity against the Adjustment Inventory by Singh and Bhargava (1980) at 0.46 .

\section{DATA COLLECTION:}

After the selection of tools, the investigator visited Doctors and Managers of selected Districts of North Maharashtra. To ensure quick and complete return of questionnaire, they were properly given to the selected sample of Doctors and Managers. After collection of data in this way, the work of scoring was done strictly according to the instruction given in the respective manuals of the tools and under the observation of Guide. The data collected was subjected to statistical processing and results were obtained.

\section{STATISTICAL ANALYSIS:}

In the present study to compare the Doctors and Managers on the self concept and Emotional Maturity one way analysis of a range of was used. For the purpose of the analysis, Descriptive statistics statistical techniques were used. The level of significance was set at 0.05 levels.

\section{RESULTS:}

H01 "There exists no significant difference between Doctors and Mangers on emotional maturity.

Table 1. Mean, Standard Deviations, and t-Value of the Doctors and Managers $(\mathrm{N}=50$ in Each Group) for Emotional Maturity.

\begin{tabular}{|l|l|l|l|l|l|}
\hline Group & $\mathrm{N}$ & Mean & S.D. & ' $\mathrm{t}$ ' Value & Level of Significance \\
\hline Doctors & 50 & 35.32 & 3.254 & \multirow{2}{*}{.724} & \multirow{2}{*}{ N.S. } \\
\hline Managers & 50 & 34.76 & 4.396 & & \\
\hline
\end{tabular}

* Significant at .05 Level.

The above table no. 1 shows the descriptive statistics of the Emotional Maturity. The Mean of Doctors35.32 and for Managers34.76, whereas for Doctors S.D. 3.254 and S.D. for Managers 4.396, obtained t-value is .724 which is found no significant at 0.05 level. Therefore, it can be concluded that the H01 "There exists no significant difference between Doctors and Mangers on emotional maturity." is selected.

H2. There exists no significant difference between Doctors and Mangers on self concept.

Table2.Mean, Standard Deviations, and t-Value of the Doctors and Managers $(\mathrm{N}=50$ in Each Group) for self concept.

\begin{tabular}{|l|l|l|l|l|l|}
\hline Group & $\mathrm{N}$ & Mean & S.D. & 't' Value & Level of Significance \\
\hline Doctors & 50 & 28.66 & 5.117 & \multirow{2}{*}{1.035} & \multirow{2}{*}{ N.S. } \\
\hline Managers & 50 & 27.64 & 4.728 & & \\
\hline
\end{tabular}

* Significant at .05 Level. 
The above table no. 2shows the descriptive statistics of the Self Concept. The Mean of Doctors28.66 and for Managers27.64, whereas for Doctors S.D. 5.117 and S.D. for Managers 4.728, obtained t-value is 1.035 which is found no significant at 0.05 level. Therefore, it can be concluded that the H02 "There exists no significant difference between Doctors and Mangers on self concept." is selected.

\section{FINDINGS}

Major findings of the present study are as under:

- There is no significant difference between the Doctors and Managers on emotional maturity.

- There is no significant difference between the Doctors and Managers on self concept.

\section{CONCLUSIONS AND DISCUSSION}

From the above said findings we can conclude that the Doctors are high on emotional maturity as compared to Managers but results not shown much differ from emotional Maturity among Doctors and Managers. Doctors are higher on self concept in comparison to Managers. Doctors and managers work profile are not same but this research result shown no difference between doctors and managers self concept and emotional maturity. The finding is supported by Thakur (2002) who in her study "Emotional Maturity as related to Home Environment" found that there exists a positive relationship between home environment and emotional maturity.Also supported by Mukherjee, J. (2000) who pointed out that emotionally mature people are mentally healthy, well adjusted and high on emotional intelligence. The performance development of any area requires integrated personality of society. Based on the finding and discussions, it could be concluded that we must enlarge positive attitude, emotional maturity and positive self concept among Doctors and Managers. Doctors and Managers self concept and Emotional Maturity helps to make the performance better.The Doctors and Managers generation should be emotionally stable and self confident to do better in their professional career and able to face the any circumstances in future.

\section{ACKNOWLEDGEMENT}

This research article is a part of my Ph. D. research work I completed at Nashik under guidance of Dr. A. R. Bhardwaj. I am highly obliged to my supervisor Dr. A. R. Bhardwaj, his support and insights have been great for my research experience. I would like to thank my Friend Bhavana for all her help, support, interest and valuable suggestions towards my study. I would like to extend my heartfelt thanks to Dr. MrunalBhardwajfor their suggestions to my study. I would like to make bigger thanks to $\mathrm{Mr}$.UmeshGirnarkar for great support for data collection. Finally I would like to thank my family for all their support, encouragement and confidence in me which has kept me energetic and devoted during the study. 


\section{REFERENCES}

1. Dhall, Shikha\&Thukral, Praveen (2009) Intelligence as Related to Self-confidence and Academic Achievement of School Students, Journal of All India Association for Educational Research, 21 (2), 80-83.

2. Dr. Mukhta Rani Rastogi (1974)Manual for Self-concept scale.

3. Garret, Henry E. (2007) Statistics in psychology and education, New Delhi: Paragon International Publishers.

4. Gill, R. \&Saini, S. (2002) Emotional maturity among institutionalized and noinstitutionalized aged in Punjab, Indian Psychological Review, 58 (3) 137-140.

5. Jha, P.K. (2002) The function of self confidence and emotional maturity in decision making style of the executives, Journal of Community Guidance and Research, 1, (3) 419-422.

6. Mamta (2006) A comparative study of emotional maturity and anxiety of under graduate and post graduate science students in Rohtak city, Unpublished M.A. (Education) Dissertation, Department of Education, M.D. University, Rohtak, Haryana.

7. Pastery, G.S. \&Aminbhavi, V.A. (2006) Impact of emotional maturity on stress and self confidence of adolescents, Journal of the Indian Academy of Applied Psychology, 32(1) 6975.

8. Singaravelu, S. (2008) Emotional maturity: A significant predictor of academic success of postgraduate students, University News, 46 (25) 17-19.

9. Singh, Y., \&Bhargava, M. (1990) Manual for Emotional Maturity Scale. Agra: National Psychological Corporation. 